ELITES, ENTERPRISE AND THE MAKING OF THE BRITISH OVERSEAS EMPIRE, 1688-1775 
Also by H. V. Bowen

A DEAR AND NOBLE BOY: THE LIFE AND LETTERS OF LOUIS STOKES, 1897-1916 (editor with R. A. Barlow)

REVENUE AND REFORM: THE INDIAN PROBLEM IN BRITISH POLITICS, 1757-1773 


\section{Elites, Enterprise and the Making of the British Overseas Empire 1688-1775}

\section{H. V. Bowen}

Lecturer in Economic and Social History

University of Leicester

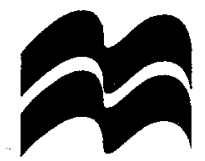


First published in Great Britain 1996 by

MACMILLAN PRESS LTD

Houndmills, Basingstoke, Hampshire RG21 6XS

and London

Companies and representatives

throughout the world

A catalogue record for this book is available

from the British Library.

ISBN 978-1-349-39311-4 ISBN 978-0-230-39019-5 (eBook)

DOI $10.1057 / 9780230390195$

First published in the United States of America 1996 by

ST. MARTIN'S PRESS, INC.,

Scholarly and Reference Division,

175 Fifth Avenue,

New York, N.Y. 10010

ISBN 978-0-312-15876-7

Library of Congress Cataloging-in-Publication Data

Bowen, H. V.

Elites, enterprise, and the making of the British overseas empire, $1688-1775 / \mathrm{H}$. V. Bowen.

p. $\mathrm{cm}$.

Includes bibliographical references and index.

ISBN 978-0-312-15876-7 (cloth)

1. Great Britain-Colonies-History-18th century. 2. Elite (Social sciences)-Great Britain-History-18th century. I. Title. JV1016.B69 1996

$325^{\prime} .341^{\prime} 08621-\mathrm{dc} 20$

(C) H. V. Bowen 1996

Softcover reprint of the hardcover 1st edition 1996 978-0-333-62208-7

All rights reserved. No reproduction, copy or transmission of this publication may be made without written permission.

No paragraph of this publication may be reproduced, copied or transmitted save with written permission or in accordance with the provisions of the Copyright, Designs and Patents Act 1988, or under the terms of any licence permitting limited copying issued by the Copyright Licensing Agency, 90 Tottenham Court Road, London W1P 9HE.

Any person who does any unauthorised act in relation to this publication may be liable to criminal prosecution and civil claims for damages.

$\begin{array}{rrrrrrrrrr}10 & 9 & 8 & 7 & 6 & 5 & 4 & 3 & 2 & 1 \\ 05 & 04 & 03 & 02 & 01 & 00 & 99 & 98 & 97 & 96\end{array}$


In memory of Philip Lawson 
This page intentionally left blank 


\section{Contents}

Preface

$\mathrm{xi}$

PART ONE CONTEXTS AND CONTOURS

1 Historians and the Eighteenth-Century Empire 3

2 The Dynamics of Expansion

PART TWO METROPOLITAN ELITES AND THE OVERSEAS EMPIRE

3 Gentlemen and Entrepreneurs: Landowners, Merchants and Bankers

4 Investment in Empire

PART THREE OVERSEAS ELITES IN THE BRITISH EMPIRE

5 Imperial Ties and the Anglicization of the Overseas Empire

6 Merchants, Planters and the Gentlemanly Ideal

PART FOUR A NEW IMPERIAL ORDER, 1750-75

7 The End of the English Empire

8 Enterprise and Expansion: Drawing a Line

Afterword

Notes

Bibliography

Index 
This page intentionally left blank 


\section{Preface}

This book does not aspire to offer comprehensive coverage and explanation of British imperial expansion during the eighteenth century. The aim is altogether more modest. This work of synthesis, based upon secondary sources, endeavours to trace the development of the forces and influences exerted by elites which served to give the empire much of its shape, coherence and direction before it was shaken by the upheavals of the 1770s. Accordingly, discussion is located in a thematic rather than strictly chronological framework of organization. Of course, there is an obvious danger in doing this, because imperialism represented a complex interaction of many forces and influences, and to focus on only one major theme invariably means that others appear to have been neglected or marginalized. Nevertheless, by concentrating attention on one central element which lay at the very heart of the development of the British empire, it is hoped that several important strands in recent historical writing can be drawn together and brought to bear on the question of how, and why, the eighteenthcentury empire acquired its form. At the same time, it must also be stressed that this book does not seek to place developments within a framework of interpretation shaped by the need to trace and explain either the causes of the American Revolution or the dissolution of what used to be referred to as the 'first British empire'. Attention is devoted to the cultural, economic and social dimensions of the British imperial experience, and an implicit assumption within the book is that analysis of political and constitutional issues serves to highlight aspects of crisis and short-term change within the empire but often tends to obscure important underlying changes and continuities. It is these underlying changes and, above all, continuities that are to be found at the core of the book.

In the past, historical analysis of the eighteenth-century British empire was often set within terms of reference defined by constitutional, military or political developments. In recent years, however, the scope of debate has broadened to include consideration of other important, but less formal, imperial sinews or bonds which held the empire together. Thus, the 
British Atlantic empire before 1775 has been variously described as an 'empire of goods' and an 'empire of paper'. That empire is also increasingly being seen as an entity in which the position of, and government by, elites was reinforced and legitimized by adherence to a set of common cultural values and assumptions, both in Britain and overseas. By drawing on these wider definitions of the imperial tie, and by considering the implications of developments taking place within the domestic economy and society, this book attempts to place eighteenthcentury British imperialism in a broad historiographical context. This allows the empire to be seen not as a series of discrete geographical areas or units scattered across the globe, but rather as a commercial, cultural and social body of reasonably sharp definition which had its roots very firmly planted in metropolitan society. It also helps with the identification of central characteristics which brought great inner strength and flexibility to the empire and allowed it to make successful adaptations to new circumstances and situations. Indeed, with one eye on the future, it is argued that it was these characteristics that eventually played a considerable part in helping Britain to survive as an imperial nation after the loss of the American colonies in 1782.

Part One, comprising two chapters, establishes the general context for the subsequent discussion. Chapter 1 marks out some key areas of debate by reviewing the recent historiography of the eighteenth-century empire, while Chapter 2 identifies some of the principal dynamic processes that contributed to the expansion of British overseas activity during the eighteenth century. The two chapters in Part Two are devoted to an assessment of how the domestic elite shaped and, in turn, were shaped by the imperial process before 1775. Chapter 3 considers the different elites who played a leading role in the activities that contributed to the expansion of the empire. These were the individuals and groups who controlled the levers of political, commercial and financial power within Britain, and their attitudes, assumptions and general outlook exerted a profound influence on the development of the metropolitan economy, society and culture. In particular, many of them were committed to a wide range of economic activities based upon innovation and improvement and they played the leading part in helping to create and sustain the enterprise culture 
that emerged at the end of the seventeenth century. As an important part of this new business environment, the expansion of British overseas interests offered an ever-increasing range of financial and commercial opportunities to the metropolitan investor, and individuals from all elites were to be found acquiring their own personal stake in the empire. At the same time, the extent to which imperialism represented an important agent of economic and social change in Britain is examined. The relationships and interactions between elite groups are assessed, and consideration is given to the way in which an interest in, and commitment to, the empire affected elite culture and attitudes in Britain. In Chapter 4, the extent to which the elite held a financial stake in the overseas empire is established. Through a wide range of investments, individuals from all the elites are shown to have been deeply implicated in the various imperial processes and it is argued that, from a metropolitan perspective, this provided the single most important link or tie between the core and the periphery of the empire.

In Part Three, the focus shifts to the wider world in an attempt to define the part played within the imperial process by the emergence of different elites in Britain's overseas possessions. The aim here is to consider the extent to which the British overseas presence was shaped and defined through local elites whose ideals, assumptions and modes of behaviour closely resembled those of the metropolitan elite. Chapter 5 identifies the way in which, from an overseas perspective, various cultural and economic ties bound the periphery to the imperial core. These imperial ties played an important role in reinforcing the position of particular overseas elites within a broader transoceanic elite. This theme is explored further in Chapter 6 through an examination of the extent to which adherence to a gentlemanly ideal enabled overseas elites to adopt lifestyles that were modelled on those of their counterparts in the mother country and which also helped their members to define their place and position within emerging local hierarchies. In all quarters of the globe, this process served to give the eighteenth-century empire at least some degree of the social order and structure that had been developed at home.

Lest it be thought that the preceding chapters have granted too sharp a sense of unity, common purpose and identity to the transoceanic imperial elite, Part Four seeks to explore two 
important areas of change in the mid-eighteenth-century empire. Both areas illustrate the extent to which relationships within, and between, different elites were in a semi-permanent state of redefinition. In Chapter 7 , the changing composition of British overseas communities is sketched against a general background in which the Englishness of the empire was being diluted, both at the core and the periphery, by the emergence of new and powerful ethnic and cultural forces. This was a reflection of the fact that an expanding empire, based upon enterprise and opportunity, offered prospects of advancement and profit to individuals from across Britain and Europe. Diversity and cosmopolitanism had become two of the dominant characteristics of the empire and this was seen quite clearly in the membership of some overseas elites. This did not necessarily weaken the empire but it illustrated the extent to which the central defining features of eighteenth-century British imperialism were sufficiently flexible and adaptable to allow different cultures, languages, religions and traditions to find a prominent place in British territories in the wider world. If cosmopolitanism did not by itself serve to weaken the empire, Chapter 8 considers other ways in which an unfettered expansionist process, based upon a vigorous and innovative enterprise culture, had begun to present new problems and difficulties to the authorities. In particular, territorial expansion prompted a metropolitan reappraisal of the basic principles underpinning imperial activity and, as this occurred, domestic elites and the overseas elite increasingly began to move out of step with one another on a wide range of issues. As those in Britain reassessed the importance of empire, so those at the periphery found some of their commercial and business ambitions becoming more restricted by the metropolitan authorities. This caused misunderstanding and tension within imperial relationships and had significant repercussions in both North America and India which fed into the general imperial crisis of the period between 1765 and 1775. Finally, brief concluding remarks address the important question of continuity within the empire by suggesting ways in which the general characteristics of the imperialism that had been developing during the eighteenth century enabled Britain to survive at a time when her very future as an imperial nation was being threatened by political crisis and military disaster. 
Because the study of imperial history has long been bedevilled by problems associated with definition, it is perhaps necessary at the outset to consider a few of the terms used in this book. Britain came into being in 1707 following the Act of Union between England and Scotland. I have thus taken care to refer to England, Scotland and Wales when examining developments located in a specific geographical context and to Britain when discussing matters relating to the greater polity that emerged after 1707. When discussing the period before the Act of Union, the empire is referred to as the English empire, and after 1707 it becomes the British empire. The overseas empire is, in the main, the territory and possessions brought under formal British control in India, North America and the West Indies. Accordingly, the 'core' of the empire is taken to be mainland Britain and the 'periphery' is British territory in the wider world. Ireland is something of a special case in the sense that it might be regarded quite legitimately as part of either the core or the periphery of the British empire. Contemporaries debated the question of Ireland's status at great length and historians have continued that discussion ever since. For the sake of convenience, I have regarded Ireland as representing, in the words of one distinguished historian, a 'kingdom and colony', but in the commentary that follows I have not defined it as belonging to the overseas empire.

I am most grateful to Philip Cottrell, P.J. Marshall and P.D.G. Thomas for their careful reading of early drafts of chapters. In their different ways, they each made many helpful comments and suggestions, and their criticism was always constructive and thought-provoking. Needless to say, of course, they bear no responsibility for what follows. I also owe a large debt to Tony Hopkins. We have not always agreed with one another, but he has been a source of great encouragement and advice as I have attempted to examine 'gentlemanly capitalism' in its eighteenth-century context. Most of all, thanks go to my family who have again offered patient and good-humoured support while a book was being written.

This book is dedicated to the memory of Phil Lawson. For me, as for many students of eighteenth-century history, his work, enthusiasm and friendship were sources of inspiration and great strength. 